\title{
Some Chemical Characteristics of Sucuk and Salami Samples Available at Retail in Adana
}

\section{Hakan Benli*}

Department of Food Engineering, Faculty of Agriculture, Cukurova University, 01330 Adana, Turkey

\begin{tabular}{l}
\hline A R T I C L E I N F O \\
Research Article \\
Received 07 June 2017 \\
Accepted 02 October 2017 \\
\hline
\end{tabular}

Keywords:

Sucuk

Salami

Chemical characteristics

Nitrate

Nitrite

*Corresponding Author:

E-mail: hbenli@cu.edu.tr \begin{abstract}
A B S T R A C T
The aim of this study was to investigate some chemical characteristics and residual nitrite and nitrate levels of sucuk and salami samples collected from retail outlets of major supermarkets in Adana province. A total of 36 sucuk samples (12 brands; 7 national and 5 local producers) and 30 salami samples (10 brands; Macar salamis) were purchased from local markets. Sucuk and salami samples were analyzed for $\mathrm{pH}$ value, moisture content, water activity and nitrite and nitrate contents. The average $\mathrm{pH}$ values of sucuk samples ranged between 4.69 and 6.56 indicating a higher variation while the average $\mathrm{pH}$ values of salami samples ranged between 6.05 and 6.43. Likewise, the average moisture contents of sucuk samples were between $33.56 \%$ and $46.78 \%$ whereas the average moisture contents of salami samples ranged between $62.09 \%$ and $67.91 \%$ indicating a relatively lower variation. Water activity values of the sucuk samples were between 0.932 and 0.861 while the average $a_{w}$ values of the salami samples ranged between 0.916 and 0.940 . Among the sucuk samples analyzed in the present study mean nitrite and nitrate contents ranged from $58.65 \mathrm{mg} / \mathrm{kg}$ to $216.63 \mathrm{mg} / \mathrm{kg}$ and $34.86 \mathrm{mg} / \mathrm{kg}$ to $161.08 \mathrm{mg} / \mathrm{kg}$, respectively. While relatively lower nitrite $(14.30 \mathrm{mg} / \mathrm{kg}-35.96 \mathrm{mg} / \mathrm{kg})$ and no nitrate contents were observed in salami samples, the data indicated that a higher variation of both nitrite and nitrate contents were still present in sucuk samples in the local markets requiring more studies and inspections to lower the variation related to dietary exposure to nitrite and nitrite from these types of products.
\end{abstract}

DOI: https://doi.org/10.24925/turjaf.v5i11.1307-1311.1357

\section{Introduction}

Sucuk is a dry or semi-dry fermented sausage produced mostly by mixing ground beef and beef fat and/or sheep tail fat with salt, sugar, nitrite or/and nitrate (cure) and some species including black pepper, red pepper, cumin, garlic. The mixture is than stuffed into natural or synthetic casings. Sucuks are fermented either by chance inoculation (natural fermentation) or by inoculating a starter culture. Fermentation and the following drying or ripening steps take place under natural or controlled climate conditions (Erkmen et al., 2004; Gencelep et al., 2008; Coskuner et al., 2010). Traditional method of producing Turkish sucuk doesn't involve any heat treatment and generally requires at least one week of ripening period while heat treated sucuks are exposed to a heat treatment following a short period of fermentation around 12 to $24 \mathrm{~h}$ (Coskuner et al., 2010).

Salami is a smoked and cooked, emulsion-type sausage produced using finely chopped mixture of lean meat, fat, cure, and spices. Extraction or solubilization of salt soluble proteins (especially myosin) is required to form meat emulsions or batters. Thus salt soluble proteins are extracted by addition of salt and water during chopping to coat the fat particles. The fat particles have tendency to form the disperse phase when the proteins and water become the continuous phase in the meat emulsions. The lipophilic portions of the proteins unfold and interact with the fat while the hydrophilic portions of the proteins interact with the aqueous phase. The salt soluble proteins behave like emulsifiers and stabilize the sausage batter by forming a viscous matrix. The texture of the emulsion-type meat products is formed by thermal transitions of the fat and protein during cooking and cooling that stabilizes the structure in finished products (Pearson et al., 1996; Aberle et al., 2001; Anar, 2010).

Sodium or potassium nitrite is added into the meat products to obtain desirable meaty flavor, prevent warmed-over flavor, develop a bright reddish pink color and inhibit microbial growth, specifically out-growth of Clostridium botulinum spores. Meat curing also involves the use of salt, seasonings and other ingredients to give unique color, flavor and texture to the meat products. Even though sodium or potassium nitrate can be used to cure the meat, nitrate is further reduced to nitrite by the microorganisms and has limited use to cure slow-cured 
products including some types of the fermented sausages (Aberle et al., 2001). In the 1970's the safety of nitrite and nitrate used for meat curing was examined since ingestion of nitrite and nitrate has potential to form carcinogenic nitrosamines in the stomach (De Gonzalez et al., 2012). However, recent researches have indicated some potential health benefits of both nitrite and nitrate due to their contribution to nitric oxide production. Nitric oxide is produced directly from nitrite and plays a significant role for cardiovascular health in the human body by controlling blood flow in the cardiac muscle (Bryan et al., 2012; De Gonzalez et al., 2012; Sindelar et al., 2012). The continuing controversy regarding human health concerns from nitrite and nitrate consumption requires periodical studies to evaluate residual nitrite and nitrate content of cured meat products. Thus, the objective of this study was to investigate some chemical characteristics and residual nitrite and nitrate levels of sucuk and salami samples collected from retail outlets of major supermarkets in Adana province and assess their safety for human consumption.

\section{Materials and Methods}

\section{Sample Collection}

A total of 36 sucuk samples (12 brands; 7 national and 5 local producers) and 30 salami samples (10 brands; Macar salamis) were purchased from local supermarkets in Adana province in 2014. Three samples of each brand were randomly collected from three different stores for analyzing. Sucuk and salami samples were kept at refrigerated temperature $\left(4^{\circ} \mathrm{C}\right)$ until analyzed for $\mathrm{pH}$, moisture, water activity, nitrite and nitrate contents.

\section{pH Values}

$\mathrm{pH}$ values of sucuk and salami samples were measured using the sample slurry method (Nielsen, 2003). The samples (approximately $10 \mathrm{~g}$ ) were placed into a blender and $90 \mathrm{ml}$ of distilled water added and blended at high speed for 30 seconds to obtain smooth slurry. An electrode of calibrated $\mathrm{pH}$ meter (InoLab $\mathrm{pH}$ Level 1, WTW GmbH \& Co. KG, Weilheim, Germany) was placed in the slurry to measure the $\mathrm{pH}$ of the samples.

\section{Moisture Contents}

The moisture contents of sucuk and salami samples were determined by taking the initial weight of the samples (approximately $5 \mathrm{~g}$ ) and then driving off the moisture in a temperature controlled $\left(100^{\circ} \mathrm{C}\right.$ for $\left.18 \mathrm{~h}\right)$ drying oven. After drying, the samples then were cooled, reweighed and the moisture contents calculated as percent moisture (Nielsen, 2003).

\section{Water Activity}

Water activity $\left(\mathrm{a}_{\mathrm{w}}\right)$ values of sucuk and salami samples were determined using a calibrated instrument of LabMASTER-aw system (Novasina, Switzerland). A sample cup was filled approximately $5 \mathrm{~g}$ of homogenized sample, placed in the measurement chamber and then $a_{w}$ values were determined when the value becomes stable on the system.

\section{Nitrite and Nitrate Contents}

Nitrite and Nitrate contents of all samples were determined using a previously described method (Dionex Corporation, 1998) with slight modifications. Sucuk and salami samples were weighed $(10.0 \mathrm{~g})$ and transferred to a blender. Deionized water $(90 \mathrm{ml})$ was added to the meat samples. The meat samples then were liquefied in the blender for 1 minute. The liquefied samples were transferred to Erlenmeyer flasks. A water bath (Memmert WNB22, Schwabach, Germany) was used to heat and maintain the temperature of the liquefied samples at $75^{\circ} \mathrm{C}$ for $15 \mathrm{~min}$. The samples were allowed to cool to the room temperature. Then the liquefied samples were transferred to centrifuge tubes and the tubes were centrifuged at 6000 $\operatorname{rpm}(4960 \times \mathrm{g})$ for $10 \mathrm{~min}$ (Heraeus Bofuge Primo R, Germany). Finally, the supernatants were passed through $0.45 \mu \mathrm{m}$ Teflon membrane filter, and then injected to the HPLC (Shimadzu LC-20AT, Japan) system equipped with a quaternary pump, a column temperature control oven (CTO-10AS), an auto sampler unit (SIL-20A), a degasser module (DGU-20A 5 ) and a photodiode array detector (SPD-M20A). $10 \mu \mathrm{l}$ of supernatant was injected into the IonPac ${ }^{\circledR}$ AS11 (Dionex, $4 \times 250 \mathrm{~mm}$ ) column. The column was kept at $30^{\circ} \mathrm{C}$. The mobile phase consists of deionized water (eluent $\mathrm{A}$ ) and $0.1 \mathrm{~N} \mathrm{NaOH}$ (eluent B). An isocratic elution system of $10 \%$ of eluent B and $90 \%$ of eluent A was used at a flow rate of $1.2 \mathrm{ml} / \mathrm{min}$ for 10 min. The photodiode array detector was set to $225 \mathrm{~nm}$. The nitrite and nitrate were identified by comparing their UV-visible spectra and retention times with that of corresponding standards. Quantification of nitrite and nitrate contents was carried out at $225 \mathrm{~nm}$ using external standard method.

\section{Statistical Analyses}

Statistical analyses of data were performed with SPSS software version 20 (IBM SPSS Statistics, Armonk, NY, USA). The study replicated three times for collecting the data. Analysis of variance (One-way ANOVA) procedures were applied and Tukey multiple comparison test was used to determine the significant differences.

\section{Results and Discussion}

The data regarding the mean $\mathrm{pH}$ values of a total of 36 sucuk samples representing 12 different brands collected from the local supermarkets are presented in Table 1. Demeyer et al. (2002) stated that the solubilized muscle proteins coagulate and form a gel surrounding fat and meat particles following the acidification produced by fermentation in fermented sausage products. When the sausage $\mathrm{pH}$ reaches 5.4 the hardness increases sharply and keeps increasing gradually until $\mathrm{pH}$ decreases 4.9 . In the present study, the average $\mathrm{pH}$ values of the samples ranged between 4.69 and 6.56 while the highest and lowest $\mathrm{pH}$ values were determined in sample 11 and sample 8 , respectively $(\mathrm{P}<0.05)$. Similarly, Çon et al. 
(1998) reported that $\mathrm{pH}$ values of 51 sucuk samples obtained from the market in ten different cities in Turkey were ranged from 4.10 to 6.31 . In another study related to surveying sucuk samples from local markets and butchers in Gaziantep region, Erkmen et al. (2004) reported that $\mathrm{pH}$ values of 50 sucuk samples varied from 4.53 to 6.74 . Gencelep et al. (2008) also reported that $\mathrm{pH}$ values of 30 sucuk samples obtained from retail markets and butchers in several cities were between 4.53 and 6.29. Furthermore, Siriken et al. (2009) reported that $\mathrm{pH}$ values of a total of 100 Turkish sucuk samples purchased from local butcher shops and retail markets in Afyon province were ranged from 4.84 to 6.50 . The previous studies and the present study indicated that $\mathrm{pH}$ values are highly variable among sucuk products that were available in local markets in different regions of Turkey. In addition, Table 2 presents the data regarding the mean $\mathrm{pH}$ values of a total of 30 salami samples representing 10 different brands collected from the local supermarkets. The average $\mathrm{pH}$ values of the samples ranged between 6.05 and 6.43 indicating a relatively lower variation among the $\mathrm{pH}$ values of the salami samples. Of the salami samples surveyed within the scope of the study, the lowest $\mathrm{pH}$ value was measured in sample 4 (6.05) while the multiple comparison tests indicated that the highest $\mathrm{pH}$ values were held by sample 2 (6.31), sample 3 (6.32), sample 7 (6.37), sample 10 (6.41), sample 5 (6.43) and sample 1 (6.43). The most of the samples were in agreement with Turkish Standard for Salami which states that salami should have a $\mathrm{pH}$ value of less than 6.4 (Anonymous, 2002).

Mean moisture values of sucuk samples are shown in Table 1. Sucuk samples had significantly different moisture contents $(\mathrm{P}<0.05)$. The average moisture values ranged between $33.56 \%$ and $46.78 \%$. Among the sucuk samples surveyed within the scope of the study, the highest moisture value was measured in sample 11 $(46.78 \%)$ while the multiple comparison tests indicated that the lowest moisture values were held by sample 10 (33.56\%), sample 1 (34.73\%), sample 3 (35.42\%), and sample 4 (35.81\%). Çon et al. (1998) stated that moisture contents of 51 sucuk samples obtained from the market in ten different cities in Turkey were ranged from $20.96 \%$ to
50.49. Similarly, Atasever et al. (1998) studied some quality characteristics of 30 sucuk samples collected from retails in Konya. It was reported that moisture values of the sucuk samples were highly variable ranging from 7 to $48.2 \%$. Likewise, Siriken et al. (2009) stated that moisture contents of 100 sucuk samples randomly purchased from local butcher shops and retail markets in Afyon province varied from $29.80 \%$ to $47.60 \%$. Table 2 shows mean moisture values of salami samples studied in the current study. Even though salami samples had significantly different moisture contents $(\mathrm{P}<0.05)$, the average moisture contents ranged between $62.09 \%$ and $67.91 \%$ indicating a relatively lower variation among the moisture values of salami samples. Among the salami samples surveyed within the scope of the study, the lowest moisture values were measured in sample $3(62.09 \%)$, sample $1(63.17 \%)$, sample $9(64.04 \%)$ and sample 10 $(64.44 \%)$ while the highest moisture values were determined in sample $4(66.93 \%)$, sample $5(67.01 \%)$, sample $8(67.58 \%)$, sample $2(67.70 \%)$, sample 6 $(67.91 \%)$ and sample $7(68.40 \%)$. Five samples were not in agreement with Turkish Standard for Salami which states that salami should have a moisture content of less than $65 \%$ (Anonymous, 2002).

Table 1 provides the mean water activity $\left(a_{w}\right)$ values of the sucuk samples studied in the present study. Among all sucuk samples, sample 11 had the highest $a_{w}$ value of $0.932(\mathrm{P}<0.05)$ while sample 10 and sample 3 had the lowest $\mathrm{a}_{\mathrm{w}}$ values of 0.861 and 0.869 , respectively $(\mathrm{P}<0.05)$. Gencelep et al. (2008) determined that $\mathrm{a}_{\mathrm{w}}$ values of 30 sucuk samples collected from retail markets and butchers in several cities ranged from 0.761 and 0.960. Similarly, Ozturk et al. (2014) reported that $a_{w}$ values of 35 sucuk samples obtained from sucuk producers ranged from 0.710 to 0.930 . In another study, Kesmen et al. (2014) indicated that $a_{w}$ values of sucuk samples collected from 8 local producers in triplicate in Kayseri were between 0.752 and 0.854 . Likewise, Table 2 provides $a_{w}$ values of the salami samples. Even though salami samples had significantly different $a_{w}$ values $(\mathrm{P}<0.05)$, the average $\mathrm{a}_{\mathrm{w}}$ values ranged between 0.916 and 0.940 indicating a relatively lower variation among $\mathrm{a}_{\mathrm{w}}$ values of the salami samples.

Table 1 Means and standard deviations for $\mathrm{pH}$, moisture, water activity, nitrite and nitrate values of sucuk samples

\begin{tabular}{c|ccccc}
\hline Sucuk $^{*}$ & $\mathrm{pH}$ & Moisture $(\%)$ & $\mathrm{a}_{\mathrm{w}}$ & Nitrite $(\mathrm{mg} / \mathrm{kg})$ & Nitrate $(\mathrm{mg} / \mathrm{kg})$ \\
\hline 1 & $4.97^{\mathrm{fg}} \pm 0.01$ & $34.73^{\mathrm{e}} \pm 0.48$ & $0.886^{\mathrm{e}} \pm 0.005$ & $58.65^{\mathrm{g}} \pm 12.87$ & $161.08^{\mathrm{a}} \pm 3.06$ \\
2 & $5.49^{\mathrm{cd}} \pm 0.45$ & $40.58^{\mathrm{cd}} \pm 3.79$ & $0.889^{\mathrm{de}} \pm 0.001$ & $110.73^{\mathrm{c}} \pm 19.06$ & $57.88^{\mathrm{ef}} \pm 7.60$ \\
3 & $5.56^{\mathrm{c}} \pm 0.08$ & $35.42^{\mathrm{e}} \pm 2.66$ & $0.869^{\mathrm{fg}} \pm 0.010$ & $77.12^{\mathrm{fg}} \pm 5.21$ & $34.86^{\mathrm{h}} \pm 1.39$ \\
4 & $6.18^{\mathrm{b}} \pm 0.02$ & $35.81^{\mathrm{e}} \pm 1.31$ & $0.874^{\mathrm{f}} \pm 0.004$ & $80.11^{\mathrm{ef}} \pm 13.97$ & $41.43^{\mathrm{gh}} \pm 8.54$ \\
5 & $4.98^{\mathrm{fg}} \pm 0.02$ & $42.24^{\mathrm{bcd}} \pm 0.38$ & $0.898^{\mathrm{cd}} \pm 0.002$ & $105.22^{\mathrm{cd} \pm 3.47}$ & $48.88^{\mathrm{fg}} \pm 0.39$ \\
6 & $4.95^{\mathrm{fg}} \pm 0.06$ & $44.28^{\mathrm{ab}} \pm 3.19$ & $0.897^{\mathrm{cd}} \pm 0.001$ & $100.13^{\mathrm{cde}} \pm 3.72$ & $71.87^{\mathrm{cd}} \pm 5.21$ \\
7 & $5.67^{\mathrm{c}} \pm 0.02$ & $44.17^{\mathrm{abc}} \pm 1.73$ & $0.911^{\mathrm{b}} \pm 0.009$ & $100.38^{\mathrm{cde}} \pm 4.70$ & $59.78^{\mathrm{e}} \pm 2.29$ \\
8 & $4.69^{\mathrm{g}} \pm 0.02$ & $43.55^{\mathrm{abc}} \pm 1.03$ & $0.916^{\mathrm{b}} \pm 0.004$ & $106.30^{\mathrm{c}} \pm 3.18$ & $95.91^{\mathrm{b}} \pm 1.26$ \\
9 & $5.13^{\mathrm{ef}} \pm 0.03$ & $43.88^{\mathrm{abc}} \pm 0.97$ & $0.907^{\mathrm{bc}} \pm 0.008$ & $84.00^{\text {def }} \pm 0.33$ & $62.29^{\mathrm{de}} \pm 6.69$ \\
10 & $5.26^{\mathrm{de}} \pm 0.23$ & $33.56^{\mathrm{e}} \pm 1.23$ & $0.861^{\mathrm{g}} \pm 0.003$ & $134.08^{\mathrm{b}} \pm 28.01$ & $80.24^{\mathrm{c}} \pm 12.29$ \\
11 & $6.56^{\mathrm{a}} \pm 0.02$ & $46.78^{\mathrm{a}} \pm 1.01$ & $0.932^{\mathrm{a}} \pm 0.006$ & $108.76^{\mathrm{c}} \pm 5.82$ & $71.40^{\mathrm{cd}} \pm 4.83$ \\
12 & $4.87^{\mathrm{fg}} \pm 0.03$ & $39.78^{\mathrm{d}} \pm 0.59$ & $0.914^{\mathrm{b}} \pm 0.006$ & $216.63^{\mathrm{a}} \pm 3.01$ & $96.30^{\mathrm{b}} \pm 1.63$ \\
\hline
\end{tabular}

"Means in the same column with different superscript letters are significantly different $(\mathrm{P}<0.05)$. 
Table 2 Means and standard deviations for $\mathrm{pH}$, moisture, water activity, nitrite and nitrate values of salami samples

\begin{tabular}{|c|c|c|c|c|c|}
\hline Salami* & $\mathrm{pH}$ & Moisture (\%) & $a_{w}$ & Nitrite $(\mathrm{mg} / \mathrm{kg})$ & Nitrate $(\mathrm{mg} / \mathrm{kg})$ \\
\hline 1 & $6.43^{a} \pm 0.03$ & $63.17^{\mathrm{c}} \pm 2.14$ & $0.934^{\mathrm{ab}} \pm 0.010$ & $23.86^{\text {bcd }} \pm 0.30$ & $\mathrm{ND}^{\delta}$ \\
\hline 2 & $6.31^{\mathrm{ab}} \pm 0.02$ & $67.70^{\mathrm{a}} \pm 0.40$ & $0.923^{a b c} \pm 0.015$ & $19.14^{\mathrm{de}} \pm 1.27$ & ND \\
\hline 3 & $6.32^{\mathrm{ab}} \pm 0.01$ & $62.09^{c} \pm 0.33$ & $0.931^{\mathrm{abc}} \pm 0.017$ & $25.92^{b c d} \pm 0.43$ & ND \\
\hline 4 & $6.05^{\mathrm{d}} \pm 0.04$ & $66.93^{\mathrm{ab}} \pm 0.60$ & $0.923^{\mathrm{abc}} \pm 0.000$ & $25.22^{\mathrm{bcd}} \pm 8.76$ & ND \\
\hline 5 & $6.43^{a} \pm 0.01$ & $67.01^{\mathrm{ab}} \pm 0.80$ & $0.920^{b c} \pm 0.010$ & $35.96^{\mathrm{a}} \pm 2.69$ & ND \\
\hline 6 & $6.05^{\mathrm{d}} \pm 0.01$ & $67.91^{\mathrm{a}} \pm 0.13$ & $0.920^{b c} \pm 0.002$ & $29.69^{a b c} \pm 2.74$ & ND \\
\hline 7 & $6.37^{\mathrm{a}} \pm 0.02$ & $68.40^{\mathrm{a}} \pm 0.38$ & $0.940^{\mathrm{a}} \pm 0.000$ & $14.30^{\mathrm{e}} \pm 4.36$ & ND \\
\hline 8 & $6.23^{b c} \pm 0.02$ & $67.58^{\mathrm{a}} \pm 1.32$ & $0.916^{\mathrm{c}} \pm 0.007$ & $20.81^{\text {cde }} \pm 0.11$ & ND \\
\hline 9 & $6.15^{\mathrm{cd}} \pm 0.16$ & $64.04^{b c} \pm 4.42$ & $0.940^{\mathrm{a}} \pm 0.001$ & $31.03^{\mathrm{ab}} \pm 10.83$ & ND \\
\hline 10 & $6.41^{\mathrm{a}} \pm 0.12$ & $64.44^{\mathrm{bc}} \pm 0.39$ & $0.935^{\mathrm{ab}} \pm 0.005$ & $17.87^{\text {de }} \pm 1.14$ & ND \\
\hline
\end{tabular}

*Means in the same column with different superscript letters are significantly different $(\mathrm{P}<0.05) .,{ }^{\delta} \mathrm{ND}$ : Not Detected

The data regarding the mean nitrite and nitrate values of sucuk samples collected from the local supermarkets are presented in Table 1. There were significant differences $(\mathrm{P}<0.05)$ among average nitrite and nitrate contents of the sucuk samples ranging from $58.65 \mathrm{mg} / \mathrm{kg}$ to $216.63 \mathrm{mg} / \mathrm{kg}$ and $34.86 \mathrm{mg} / \mathrm{kg}$ to $161.08 \mathrm{mg} / \mathrm{kg}$, respectively. Of the sucuk samples analyzed in the present study, sample 12 that was produced by a local producer in Adana province, had the highest mean nitrite content of $216.63 \mathrm{mg} / \mathrm{kg}(\mathrm{P}<0.05)$ while the second highest nitrite content was detected in sample $10(134.08 \mathrm{mg} / \mathrm{kg})$. The difference between these two samples indicated that sample 12 contained more than $82.55 \mathrm{mg} / \mathrm{kg}$ residual nitrite when compared to other samples surveyed in the present study. Conversely, the lowest mean nitrite content of $58.65 \mathrm{mg} / \mathrm{kg}$ was found in sample 1 which was manufactured by a national producer. In contrast to the nitrite contents, the highest nitrate value was determined in sample $1(161.08 \mathrm{mg} / \mathrm{kg})$. Of all sucuk samples, the lowest nitrate value was found in sample $3(34.86 \mathrm{mg} / \mathrm{kg})$. In a previous study, Soyutemiz et al. (1996) studied the nitrite and nitrate contents of processed meats including 25 sucuk samples obtained from local markets in Bursa. They reported that nitrite and nitrate values of sucuk samples were between 1.55 and $18.75 \mathrm{mg} / \mathrm{kg}$ and 0 and $618.86 \mathrm{mg} / \mathrm{kg}$, respectively. Similarly, Sancak et al. (2008) reported that nitrite and nitrate contents of 40 sucuk samples obtained from the local market in Van ranged from 0.80 to $82.13 \mathrm{mg} / \mathrm{kg}$ and 1.56 to 553.18 $\mathrm{mg} / \mathrm{kg}$, respectively. Likewise, Buyukunal et al. (2016) indicated that nitrite values of 132 sucuk samples collected from producers and retailers in several cities ranged from 6.41 to $90.02 \mathrm{mg} / \mathrm{kg}$ and 28.10 to 174.62 $\mathrm{mg} / \mathrm{kg}$. In another study, Doğu et al. (2002) also stated that nitrite values of 30 sucuk samples collected from 5 high capacity meat plants in Afyon were between 41.80 and $631.03 \mathrm{mg} / \mathrm{kg}$. In addition, Table 2 presents the data regarding the mean nitrite values of salami samples collected from the local supermarkets. There were significant differences $(\mathrm{P}<0.05)$ among average nitrite values of the salami samples ranging from $14.30 \mathrm{mg} / \mathrm{kg}$ to $35.96 \mathrm{mg} / \mathrm{kg}$ indicating a relatively low variation among to the samples when compared to that of the variation among the sucuk samples $(58.65 \mathrm{mg} / \mathrm{kg}$ to $216.63 \mathrm{mg} / \mathrm{kg})$. Of the salami samples analyzed within the scope of the study, sample $5(35.96 \mathrm{mg} / \mathrm{kg})$, sample $9(31.03 \mathrm{mg} / \mathrm{kg})$ and sample $6(29.69 \mathrm{mg} / \mathrm{kg})$ had the highest nitrite levels $(\mathrm{P}<0.05)$ while the lowest mean nitrite values of 14.30 $\mathrm{mg} / \mathrm{kg}, 17.87 \mathrm{mg} / \mathrm{kg}, 19.14 \mathrm{mg} / \mathrm{kg}$, and $20.81 \mathrm{mg} / \mathrm{kg}$ were found in sample 7 , sample 10, sample 2 and sample 8 , respectively. Among the all salami samples analyzed in the present study, nitrate residue was not detected in any of the samples. Conversely, Soyutemiz et al. (1996) reported that a relatively higher variation for both nitrite and nitrate values of 15 salami samples obtained from the local market ranging from 8.01 to $157.91 \mathrm{mg} / \mathrm{kg}$ and from 7.44 to $349.95 \mathrm{mg} / \mathrm{kg}$, respectively. In another study, Işıklı (2001) reported that nitrite values of 70 salami samples obtained from several producers were between 3.46 and $676.97 \mathrm{mg} / \mathrm{kg}$. Furthermore, Sezer et al. (2013) reported that nitrite and nitrate values of 15 salami samples purchased from local markets were ranged from 163 to $532 \mathrm{mg} / \mathrm{kg}$ and 98 to $293 \mathrm{mg} / \mathrm{kg}$, respectively. Comminuted products including sucuk and salami are allowed a maximum ingoing concentration of $150 \mathrm{mg} / \mathrm{kg}$ of sodium or potassium nitrite or nitrate during the production (Türk Gida Kodeksi, 2013) in Turkey. Although relatively lower nitrite and no nitrate contents were observed in the salami samples, previous studies and the present study indicated that both nitrite and nitrate contents are still highly variable among the sucuk products that are available in local markets in different regions of Turkey.

\section{Conclusion}

The present study and some previous studies indicated that some chemical characteristics including $\mathrm{pH}$ (4.69$6.56)$, moisture $(33.56 \%$ and $46.78 \%), \mathrm{a}_{\mathrm{w}}(0.932-0.861)$, nitrite $(58.65 \mathrm{mg} / \mathrm{kg}-216.63 \mathrm{mg} / \mathrm{kg})$ and nitrate $(34.86$ $\mathrm{mg} / \mathrm{kg}$ to $161.08 \mathrm{mg} / \mathrm{kg}$ ) contents of the sucuks are highly variable in local markets in Turkey. In contrast to previous studies, the salami samples studied in this study showed less variation mainly for the nitrite and nitrate contents indicating improved standardized procedures in producing these types of products in the recent years. However, the higher variation of both nitrite and nitrate contents observed particularly in sucuk samples in the local markets requires more studies and inspections to lower the variation related to dietary exposure to nitrite and nitrite from these types of products. 


\section{Acknowledgments}

The author extends special thanks to the undergraduate students in the Food Engineering Department at Cukurova University for their assistance in the present study.

\section{References}

Aberle ED, Forrest JC, Gerrard DE, Mills EW, Hedrick HB, Judge MD, Merkel RA. 2001. Principles of meat science. Dubuque, Iowa: Kendall/Hunt Publishing Company. ISBN 0787247200.

Anar Ş. 2010. Et ve et ürünleri teknolojisi. Bursa: Dora. ISBN 9786054118571.

Anonymous. 2002. Salam (salami). Turkish Standards Institute (TS 979).

Atasever M, Keleş A, Güner A, Uçar G. 1998. Konya'da tüketime sunulan fermente sucukların bazı kalite nitelikleri. Avrasya Veteriner Bilimleri Dergisi. 14(2): 27-32.

Bryan NS, Alexander DD, Coughlin JR, Milkowski AL, Boffetta P. 2012. Ingested nitrate and nitrite and stomach cancer risk: An updated review. Food Chem Toxicol. 50(10): 3646-3665. doi:10.1016/j.fct.2012.07.062

Buyukunal SK, Sakar FS, Turhan I, Erginbas C, Sandikci Altunatmaz S, Yilmaz Aksu F, Yilmaz Eker F, Kahraman T. 2016. Presence of salmonella spp., listeria monocytogenes, escherichia coli o157 and nitrate-nitrite residue levels in turkish traditional fermented meat products (sucuk and pastirma). Kafkas Univ Vet Fak. 22(2): 233-236. doi:10.9775/kvfd.2015.14238

Coskuner O, Ertas AH, Soyer A. 2010. The effect of processing method and storage time on constituents of turkish sausages (sucuk). J Food Process Preserv. 34: 125-135. doi:DOI 10.1111/j.1745-4549.2008.00328.x

Çon AH, Gökalp HY. 1998. Türkiye pazarındaki sucukların bazı kimyasal ve mikrobiyolojik nitelikleri. Gıda. 23(3): 347-355.

De Gonzalez MTN, Osburn WN, Hardin MD, Longnecker M, Garg HK, Bryan NS, Keeton JT. 2012. Survey of residual nitrite and nitrate in conventional and organic/natural/uncured/indirectly cured meats available at retail in the united states. J Agric Food Chem. 60(15): 3981-3990. doi:Doi 10.1021/Jf204611k

Demeyer D, Stahnke L. 2002. Quality control of fermented meat products. In: Kerry J, Kerry J, Ledward D. Meat processing : Improving quality. Boca Raton, FL: CRC Press. p 464. ISBN 0849315395.

Dionex Corporation. 1998. Application note 112 - determination of nitrate and nitrite in meat using high-performance anionexchange chromatography. http://tools.thermofisher.com/content/sfs/brochures/4069AN112_LPN0837-01.pdf. Accessed 13 April 2017.
Doğu M, Çon AH, Gökalp HY. 2002. Afyon ilindeki yüksek kapasiteli et işletmelerinde üretilen sucukların bazı kalite özelliklerinin periyodik olarak belirlenmesi. Turk J Vet Anim Sci. 26: 1-9.

Erkmen O, Bozkurt H. 2004. Quality characteristics of retailed sucuk (turkish dry-fermented sausage). Food Technol Biotechnol. 42(1): 63-69.

Gencelep H, Kaban G, Aksu MI, Oz F, Kaya M. 2008. Determination of biogenic amines in sucuk. Food Control. 19(9): 868-872. doi:DOI 10.1016/j.foodcont.2007.08.013

Işıklı ND. 2001. Et ürünlerinde nitrit tayininde kullanılan yöntem teşhis limitinin belirlenmesi. Gıda. 26(5): 347-351.

Kesmen Z, Yarimcam B, Aslan H, Ozbekar E, Yetim H. 2014. Application of different molecular techniques for characterization of catalase-positive cocci isolated from sucuk. J Food Sci. 79(2): M222-M229. doi:10.1111/1750-3841.12328

Nielsen SS. 2003. Food analysis. 3rd Edition., New York: Kluwer Academic/Plenum Publishers. ISBN 0306474956.

Ozturk I, Sagdic O. 2014. Biodiversity of yeast mycobiota in "sucuk," a traditional turkish fermented dry sausage: Phenotypic and genotypic identification, functional and technological properties. J Food Sci. 79(11): M2315-M2322. doi:10.1111/1750-3841.12662

Pearson AM, Gillett TA. 1996. Processed meats. 3rd Edition., New York: Chapman \& Hall. ISBN 0412064413 (cl alk. paper).

Sancak YC, Ekici K, İşleyici Ö. 2008. Fermente türk sucuğu ve pastırmalarda kalıntı nitrat ve nitrit düzeyleri. Yüzüncü Y1l Üniversitesi Veteriner Fakültesi Dergisi. 19(1): 41-45.

Sezer Ç, ÖĞÜN M, GÜVen A. 2013. Determination of some chemical characteristics of salami and sausage. Kafkas Univ Vet Fak. doi:10.9775/kvfd-2013-7200

Sindelar JJ, Milkowski AL. 2012. Human safety controversies surrounding nitrate and nitrite in the diet. Nitric Oxide. 26(4): 259-266. doi:10.1016/j.niox.2012.03.011

Siriken B, Cadirci O, Inat G, Yenisey C, Serter M, Ozdemir M. 2009. Some microbiological and pysico-chemical quality of turkish sucuk (sausage). J Anim Vet Adv. 8(10): 2027-2032.

Soyutemiz GE, Özenir A. 1996. Bursa'da tüketilen sucuk, salam, sosis ve pastırmalardaki kalıntı nitrat ve nitrit miktarlarının saptanmas1. G1da. 21(6): 471-476.

Türk Gıda Kodeksi. 2013. Türk gıda kodeksi gıda katkı maddeleri yönetmeliği.

http://www.mevzuat.gov.tr/Metin.Aspx?MevzuatKod=7.5.1853 2\&MevzuatIliski=0\&sourceXmlSearch=katk\%C4\%B1. Accessed 1 June 2017. 